\section{Note}

\section{Sweet Taste Responses of Fly to Furanoses and their Analogues}

\author{
Hiroshi OHRuI, Hiroyuki HorIKI, \\ Ichiro ShimadA* and Hiroshi Meguro
}

Department of Food Chemistry, Faculty of Agriculture,

Tohoku University, 1-1,

Tsutsumidori-Amamiyamachi, Sendai 980, Japan

Received April 17, 1985

Since 1960, the sugar receptor sites of fly have been suggested to be different for pyranose and furanose. ${ }^{1)}$ Shimada, one of the authors, has examined the responses of sugar receptors of the fleshfly (Boettcherisca peregrina) to various sugars and clearly showed the existence of two different receptor sites: the "pyranose receptor site" responds to glucose and cyclitols which have three continuous equatorial hydroxy groups and is inhibited by treatment with $p$-chloromercuribenzoate, and the "furanose receptor site" responds to D-fructose and is not inhibited by the $p$-chloromercuribenzoate treatment. ${ }^{2)}$ Although the number of pyranoses tested was enough to suggest the structure of the "pyranose receptor site" in the fleshfly, the limited number of furanoses tested was inadequate to elucidate the structure-taste relationship. The structure of $D$-fructose responsible for the response was considered to be $\beta$-D-fructofuranose on the basis of the relationship between its degree of response and optical rotation. ${ }^{2)}$

In this report, the responses of the sugar receptor of the fleshfly to 16 tetrahydrofuran derivatives and 8 fivemembered lactones were examined. All the compounds are known. Several of them $(1,14,15,16,17,18,19,20,21$, 22) were purchased from Sigma Company Ltd. and the others were prepared according to the reported methods. ${ }^{3 \sim 14)}$

$0.5 \mathrm{M} \mathrm{NaCl}$
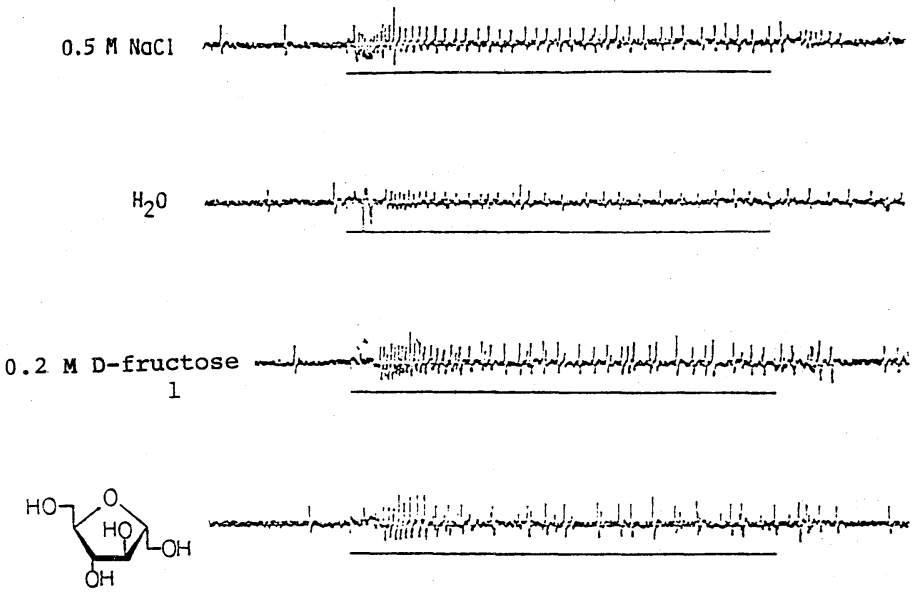

2

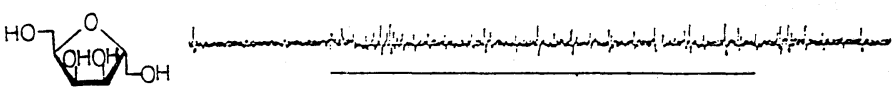<smiles>O=C1O[C@H](O)[C@H]2OC1C2O</smiles>

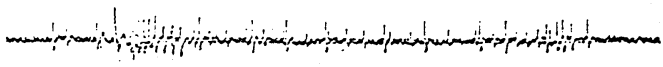

14

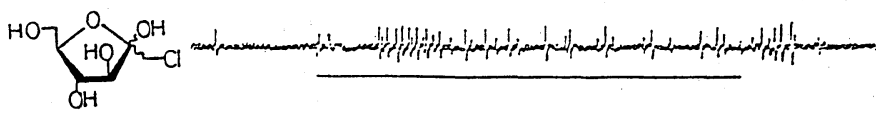

23

$1 \mathrm{mV}$

\title{
$200 \mathrm{~m} \mathrm{sec}$
}

FIG. 1. Spikes from the Sugar Receptor Cell.

* Department of Biological Science, Tohoku University. 


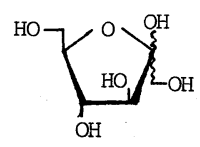

D-fructofuranose
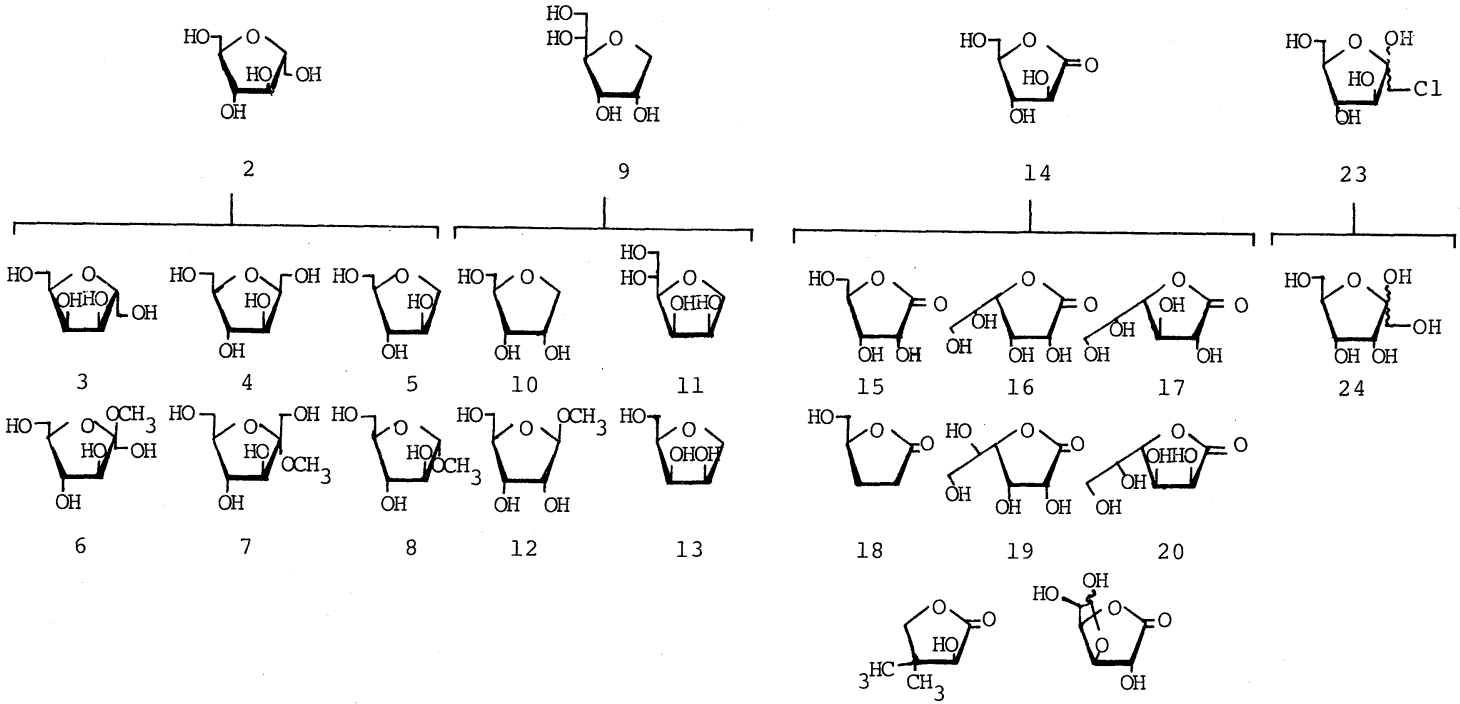

17

Fig. 2. Structures of Tested Compounds.

Table I. Relative Responses of the Compounds at $0.2 \mathrm{M}$ Concentration

\begin{tabular}{|c|c|c|c|}
\hline \multirow{2}{*}{ Compound } & \multirow{2}{*}{ (Identity) } & \multicolumn{2}{|c|}{$\begin{array}{l}\text { Relative response } \pm \text { S.D. } \\
\text { (number of tests) }\end{array}$} \\
\hline & & $0.2 \mathrm{M}$ & \\
\hline D-Fructose & (1) & 1.00 & \\
\hline 2,5-Anhydro-D-mannitol & ( 2$)$ & $0.31 \pm 0.24$ & (16) \\
\hline 2,5-Anhydro-D-talitol & ( 3$)$ & $0.04 \pm 0.07$ & ( 8 ) \\
\hline 2,5-Anhydro-D-glucitol & (4) & $0.15 \pm 0.09$ & (10) \\
\hline 1,4-Anhydro-D-arabinitol & ( 5$)$ & $0 \pm 0$ & ( 8 ) \\
\hline Methyl $\beta$-D-fructofuranoside & ( 6) & $0 \pm 0$ & ( 5$)$ \\
\hline Methyl $\alpha$-D-fructofuranoside & ( 7 ) & $0 \pm 0$ & ( 5$)$ \\
\hline Methyl $\alpha$-D-arabinofuranoside & ( 8 ) & $0.01 \pm 0.04$ & ( 7 ) \\
\hline 1,4-Anhydro-D-allitol & (9) & $0.24 \pm 0.24$ & ( 9 ) \\
\hline 1,4-Anhydro-D-ribitol & (10) & $0.07 \pm 0.14$ & (9) \\
\hline 1,4-Anhydro-D-mannitol & (11) & $0 \pm 0$ & ( 6 ) \\
\hline Methyl $\beta$-D-ribofuranoside & (12) & $0 \pm 0$ & (10) \\
\hline 1,4-Anhydro-D-lyxitol & (13) & $0.02 \pm 0.05$ & ( 9 ) \\
\hline D-Arabono- $\gamma$-lactone & (14) & $0.32 \pm 0.15$ & ( 8 ) \\
\hline D-Ribono- $\gamma$-lactone & (15) & $0.01 \pm 0.04$ & ( 7$)$ \\
\hline (4S)-4,5-Dihydroxypentanoic acid 1,4-lactone & (16) & $0 \pm 0$ & (10) \\
\hline D-Gulono- $\gamma$-lactone & (17) & $0.16+0.19$ & (6) \\
\hline L-Manno- $\gamma$-lactone & (18) & $0 \pm 0$ & ( 5$)$ \\
\hline D-Talono- $\gamma$-lactone & (19) & $0 \pm 0$ & ( 5$)$ \\
\hline D-Galactono- $\gamma$-lactone & (20) & $0 \pm 0$ & (10) \\
\hline L-Pantonyl lactone & (21) & $0.03 \pm 0.06$ & (10) \\
\hline D-Glucurono- $\gamma$-lactone & (22) & $0.08 \pm 0.12$ & (6) \\
\hline 1-Chloro-1-deoxy-D-fructose & (23) & $0.18 \pm 0.12$ & ( 8 ) \\
\hline D-Psicose & (24) & $0.17 \pm 0.17$ & (12) \\
\hline
\end{tabular}


The examination was an electrophysiological one based on measuring the number of impulses caused by contacting the sugar solution with the tip of the taste hair, the details for which have been reported in the literature. ${ }^{2)}$

The representative impulses obtained are shown in Fig. 1. The structures and the relative responses of the compounds at $0.2 \mathrm{M}$ concentration are shown in Fig. 2 and Table I, respectively.

Four tetrahydrofuran derivatives 1, 2, 9, 23, and one aldono- $\gamma$-lactone 14 were effective among these compounds. This indicates that there really exists a "furanose receptor site." The responses to the compounds 4,17 and 24 were judged nonstimulative, since they were independent of their concentrations. The response of 1,4anhydro-allitol (9) was inhibited by the $p$ chloromecuribenzoate treatment, and therefore, the receptor site of $\mathbf{9}$ was different from that of the other effective compounds.

All the effective compounds had the common structure A. However, not all the compounds with the structure A were effective. This indicates that both the kind of substituents at C-1 of A and their stereochemistry were very important. The result that $\mathbf{2}$ was effective and $\mathbf{4}$ was not indicates that the stimulative structure of $\mathrm{D}$-fructose should be $\beta$-D-fructofuranose as was previously supposed. ${ }^{2)}$

\section{REFERENCES}

1) H. Morita, K. Enomoto, M. Nakashima, I. Shimada and H. Kijima, "Olfaction and Taste VI," Information Retrieval Ltd., 1977, p. 39.

2) I. Shimada, A. Shiraishi, H. Kijima and H. Morita, J. Insect Physiol., 20, 605 (1974).

3) D. Horton and K. D. Philips, Carbohyd. Res., 30, 367 (1973).

4) J. Defaye, Bull, Chim. Fr., 999 (1964).

5) T. A. W. Koerner, Jr., R. J. Voll and E. S. Younathan, Carbohydr. Res., 59, 403 (1977).

6) Y. Rabinsohn and H. G. Fletcher, Jr., J. Org. Chem., 32, 3452 (1967).

7) C. B. Purves and C. S. Hudson, J. Am. Chem. Soc., 56, 708 (1934).

8) E. M. Montogomery and C. S. Hudson, J. Am. Chem. Soc., 59, 992 (1937).

9) R. Baker and H. G. Fletcher, Jr., J. Org. Chem., 26, 4605 (1961)

10) F. Weygand and W. G. Overland, J. Chem. Soc., 1132 (1951)

11) H. G. Fletcher, Jr. and H. W. Diehl, J. Am. Chem. Soc., 74, 3175 (1952).

12) M. Cifonelli, J. A. Cifonelli, R. Montogomery and F. Smith, J. Am. Chem. Soc., 77, 121 (1955).

13) C. R. Haylock, L. D. Melton, K. N. Slessor and A. S. Tracy, Carbohydr. Res., 16, 375 (1971).

14) K. James, A. R. Tatchell and P. K. Ray, J. Chem. Soc. (C), 2681 (1967) 